\title{
Penggunaan Smartphone sebagai Pengembangan Bahan Ajar Elektronik Pada Mata Kuliah Matematika Dasar
}

\author{
Gilang Ary Sandy ${ }^{1}$, Sulistyahadii ${ }^{2}$ \\ ${ }^{1,2}$ STKIP Muhammadiyah Manokwari \\ e-mail:*1gilang.ary.sandy@gmail.com,*2tyohadi@gmail.com
}

\begin{abstract}
Abstrak
Penelitian ini merupakan pengembangan bahan ajar elektronik untuk melihat penguasaan penggunaan teknologi mahasiswa dan pengaruhnya terhadap peningkatan kemampuan pembelajaran matakuliah matematika dasar. Jenis penelitian ini adalah research and development $(R \& D)$ dengan desain $4 D$, yaitu tahap define, design, develop, dan disseminate yang dibatasi sampai tahap develop. Tahap pengembangan dilakukan validasi bahan ajar kemudian uji terbatas dan uji luas. Sampel dalam uji terbatas dan uji luas adalah Mahasiswa Program Studi Bahasa Inggris di STKIP Muhammadiyah Manokwari. Semua hasil penilaian yang diperoleh dari mahasiswa dianalisis dengan skoring menggunakan angket. Angket respons terhadap penggunaan produk memiliki empat pilihan jawaban sesuai konten pertanyaan, misalnya "sangat menarik", "menarik", "kurang menarik", dan "tidak menarik". Masing-masing pilihan jawaban memiliki skor berbeda yang mengartikan tingkat kesesuaian produk bagi pengguna. Hasil dari skor penilaian tersebut kemudian dicari rata-ratanya dari sejumlah subyek sampel uji coba dan dikonversikan ke pernyataan penilaian untuk menentukan tingkat kemenarikan, kemudahan dan kemanfaatan bahan ajar elektronik yang dihasilkan.
\end{abstract}

Kata kunci: Bahan ajar elektronik, Mobile learning, Smartphone

\section{PENDAHULUAN}

Perkembangan teknologi perangkat bergerak (mobile device) yang pesat memberikan peluang dalam pengembangan media pembelajaran bergerak (mobile learning). Mobile learning memudahkan para peserta didik untuk belajar kapan saja dan di mana saja. Strategi tersebut memudahkan para peserta didik untuk menguasai kompetensi materi secara utuh dalam waktu yang lebih cepat dari media pembelajaran yang lain (Jazuli, dkk., 2017). Salah satu inovasi dalam perkembangan teknologi modern seperti penggunaan smartphone sebagai pengembangan bahan ajar elektronik.

Penggunaan teknologi dalam pembelajaran melahirkan berbagai inovasi pembelajaran salah satunya yaitu dikenal dengan m-learning (mobile learning). Istilah m-learning (mobile learning) merujuk pada penggunaan produk teknologi modern yang bersifat praktis seperti PDAs, iPod, PC Tablet, dan Ponsel atau smartphone dalam proses pembelajaran, sehinga memudahakan peserta didik untuk belajar lebih praktis dan fleksibel. M-Learning sebagai inovasi pendidikan dalam proses pembelajaran pada dasarnya tersedia dalam 2 versi yaitu versi offline dan versi online

Versi offline dapat dibuat dengan cara merancang aplikasi sesuai kebutuhan misalnya media belajar, bahan ajar, dan aplikasi edukasi yang lain kemudian di pasang (install) ke perangkat mobile seperti handphoen dan smartphone (Dwiyogo, 2013). Aplikasi edukasi yang sudah terpasang di perangkat mobile tersebut dapat di akses secara berulang tanpa harus memasang ulang. Sedangkan versi online membutujkan akses internet untuk keberlangsungan proses pembelajaran. Darmawan (2012) menyatakan bahwa terdapat beberapa alasan pengembangan teknologi handphone/smartphone sebagai landasan operasional munculnya inovasi mobile

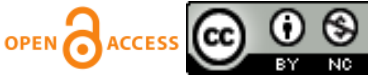


learning yaitu: penetrasi perangkat mobile (handphone/smartphone) sangat cepat, jumlahnya lebih banyak dibagndingkan dengan PC, lebih mudah dioprasikan dibandingkan PC, dan perangkat mobile (handphone/smartphone) dapat dipakai sebagai media belajar. M-learning memiliki berbarapa fungsi diantaranya yaitu: m-learning berfungsi sebagai pelengkap (komplemen), m-learning berfungsi sebagai pengayaan (enrichement), dan m-learning berfungsi sebagai remedial (Dwiyogo, 2013).

Manfaat penerapan m-learning bagi peserta didik, yaitu dapat meningkatkan fleksibiltas belajar. Sedangkan bagi pendidik $m$-learning mempermudah dalam pemutahkiran bahan-bahan belajar yang menjadi tanggung jawabnya sesuai dengan tuntutan perkembangan keilmuan Selain itu, penyampaikan materi pelajaran yang bersifat abstrak dengan adanya visualiasi yang jelas dan menarik melalui perangkat mobile yang diguanakan dalam m-learning (Dwiyogo, 2013).

Smartphone dapat digunakan sebagai inovasi untuk pengembangan bahan ajar elektronik, karena mahasiswa dapat mempelajari mata kuliah dengan cara yang berbeda, yaitu memanfaatkan smartphone sebagai media pembelajaran. M-Learning dengan menggunakan smartphone adalah pembelajaran yang unik karena pebelajar dapat mengakses materi pembelajaran, arahan dan aplikasi yang berkaitan dengan pembelajaran, kapan-pun dan dimana-pun melalui perangkat. Selain membuat mata kuliah lebih menarik, mahasiswa dapat mempelajari materi tanpa terbatas waktu, artinya mahasiswa dapat belajar di luar jam kuliah, sehingga akan memberikan dampak positif bagi mahasiswa dalam penggunaan smartphone sebagai sarana belajar. Hal ini akan meningkatkan perhatian pada materi pembelajaran, membuat pembelajaran menjadi persuasif dan dapat mendorong motivasi pembelajar kepada pembelajaran sepanjang hayat (lifelong learning). Pelajaran yang disusun secara runtut dan sistematis serta menampilkan sosok utuh dari kompetensi yang akan dikuasai mahasiswa dalam kegiatan pembelajaran. Menurut Sungkono dkk. (2003) Bahan Pembelajaran adalah seperangkat bahan yang memuat materi atau isi pembelajaran yang "didesain" untuk mencapai tujuan pembelajaran.

Pembelajaran merupakan suatu tindakan sadar dari seorang pendidik untuk membelajarkan para peserta didiknya dalam rangka mencapai suatu tujuan yang dikehendaki (Sugiyono, 2005). Salah satu faktor yang berpengaruh pada sistem pembelajaran adalah adanya sarana pembelajaran seperti media, alat-alat pembelajaran, perlengkapan, yang mendukung kelancaran proses pembelajaran itu sendiri (Sanjaya dan Wina, 2013).

Media adalah segala sesuatu yang dapat dipergunakan untuk menyalurkan pesan dari pengirim pesan ke penerima pesan sehingga merangsang pikiran, perasaan, serta perhatian peserta didik sedemikian rupa sehingga proses belajar terjadi (Prastowo, 2011). Apabila suatu media dapat membawa pesan atau informasi yang bertujuan intruksional atau mengandung maksud-maksud pengajaran, maka media tersebut dikatakan sebagai media pembelajaran (Arsyad, 2013). Komponen penting yang lain yaitu ketersediaan bahan ajar yang dapat digunakan oleh peserta didik. Bahan ajar adalah separangkat materi yang disusun secara sistematis yang dapat digunakan oleh peserta didik sehingga tercipta suatu kondisi yang memungkinkan peserta didik belajar dengan baik. Bahan ajar merupakan segala bentuk bahan yang tertulis maupun tidak tertulis yang digunakan untuk membantu pendidik (guru, dosen, maupun instruktur) dalam melaksanakan proses pembelajaran di kelas (Prastowo, 2011)

Bahan ajar dilihat dari bentuknya, meliputi: bahan ajar cetak, yaitu berbagai bahan yang disajikan dalam kertas cetak, seperti buku, handout, modul, dan lain-lain; bahan ajar dengar atau audio, contohnya kaset, radio, pringan hitam, dan compact disk audio; bahan ajar audio visual, contohnya, film dan video; dan bahan ajar interaktif (interactive teaching material), yakni kombinasi dari dua atau lebih media (teks, gambar, grafik, animasi, audio, dan video) yang dimanipulasi atua diberi perlakuan untuk mengendalikan suatu perintah, contohnya compact disk interaktif (Prastowo, 2011).

Bahan ajar dilihat dari bentuknya, meliputi: bahan ajar cetak, yaitu berbagai bahan yang disajikan dalam kertas cetak, seperti buku, handout, modul, dan lain-lain; bahan ajar dengar atau audio, contohnya kaset, 
radio, pringan hitam, dan compact disk audio; bahan ajar audio visual, contohnya, film dan video; dan bahan ajar interaktif (interactive teaching material), yakni kombinasi dari dua atau lebih media (teks, gambar, grafik, animasi, audio, dan video) yang dimanipulasi atua diberi perlakuan untuk mengendalikan suatu perintah, contohnya compact disk interaktif (Jazulil dkk., 2017)

Bahan ajar dilihat dari cara kerjanya, meliputi: bahan ajar yang tidak diproyeksikan, maksudnya yaitu tidak memerlukan prangkat proyektor untuk menampilkan isinya; bahan ajar yang diproyeksikan, yakni memerlukan alat proyektor agar isi bahan ajar bisa dimanfaatkan, misalnya slide; bahan ajar audio dan video, yakni bahan ajar yang membutuhkan alat pemain/pemutar seperti CD player, VCD player, dan multimedia player; dan bahan ajar komputer, yakni bahan ajar noncetak yang membutuhkan komputer untuk mengakses isinya agar bisa digunakan untuk belajar.

Bahan ajar dilihat dari sifatnya, meliputi; bahan ajar berbasis cetak, seperti pamphlet, buku, panduan belajar siswa, dan lain sebagainya; bahan ajar berbasiskan teknologi, misalnya audio cassete siaran radio, film, slide, televisi, multimedia, dan lain sebagainya; bahan ajar yang digunakan untuk praktik, misalnya kit sains, lembar observasi, dan sebagainya; dan bahan ajar untuk keperlukan interaksi manusia (pendidikan jarak jauh), misalnya hand phone, video conferencing, telepon, dan sebagainya (Munadi, 2013)

Tinjauan cara kerjanya bahan ajar elektronik yang dikembangkan termasuk dalam kategori bahan ajar yang tidak diproyeksikan, dan jika dilihat dari sifatnya termasuk dalam kategori bahan ajar yang berbasiskan teknologi elektronik modern, dalam hal ini berupa perangkat elektronik yaitu smartphone berbasis android yang mendukung konten multimedia. Isi suatu bahan ajar substansinya meliputi: pengetahuan, yaitu berupa fakta, konsep, prinsip, dan prosedur; keterampilan, yaitu berupa bahan pembelajaran yang berkenaan dengan kemampuan mengembangkan suatu ide, menetapkan atau memilih, menggunakan bahan atau peralatan, dan teknik kerja; dan sikap atau nilai, yaitu isi bahan ajar yang berkenaan dengan sikap ilmiah seperti kejujuran (objektif) dalam melakukan observasi dan tidak memanipulasi data hasil eksperimen, nilai kebersamaan dalam kegiatan berkelompok, nilai semangat dan minat belajar/bekerja, nilai tolong-menolong antar sesama, dan menerima pendapat orang lain (Prastowo, 2011).

Pembagian bahan ajar menjadi beberapa kategori yaitu, meliputi: bahan cetak (visual) seperti buku, handout, leaflet, walchart, brosur, gambar, maket., bahan dengar (audio) seperti tape recorder, radio, kaset, bahan pandang dengar (audio visual) seperti video compact disk, film, bahan ajar interaktif seperti CD interaktif (Munadi, 2013). Selain itu, kategori bahan ajar menjadi 3 kelompok besar berdasarkan bentuk, cara kerja, dan sifatnya (Prastowo, 2011).

Mahasiswa tersebut merupakan calon guru Bahasa Inggris yang diharapkan untuk menguasai teknologi secara aktif. Selain itu, mahasiswa mengalami kesulitan dalam memahami perkuliahan matematika dasar. Hal ini terlihat dengan nilai matematika dasar yang pada umumnya masih kurang. Faktor kurang menarik dan susah untuk dipahami sehingga mahasiswa mengalami kesulitan dalam memahami perkulihan matematika dasar. Oleh sebab itu, menjadi sebuah tantangan untuk mengembangkan bahan ajar elektronik menggunakan smartphone. Bahan ajar elektronik dijadikan pembelajaran yang digunakan dan diujikan di mahasiswa/i program studi (Prodi) pendidikan Bahasa inggris di STKIP Muhammadiyah Manokwari.

Tujuan penelitian ini menguasai teknologi secara aktif, sehingga kedepannya pendidikan dengan menggunakan teknologi bisa diterapkan di sekolah di Papua Barat khususnya Manokwari. Secara khusus penelitian ini untuk mengukur tingkat pemahaman mahasiswa terhadap mata kuliah matematika dasar yang merupakan mata kuliah yang sulit. Diharapkan dengan menggunakan smartphone sebagai pengembangan bahan ajar elektronik kemampuan mahasiswa meningkat dari segi penguasaan mata kuliah dan teknologi.

Bahan ajar elektronik yang telah dikembangkan dijadikan pembelajaran yang digunakan dan diujikan di mahasiswa. Deskripsi keterlaksanaan pembelajaran mahasiswa menggunakan bahan ajar elektronik berbasis m-learning menggunakan smartphone pada mata kuliah matematika dasar untuk menerapkap penggunaan 
teknologi secara aktif. Pengembangan bahan ajar elektronik direncanakan berisi tiga bab materi yang saling terkait. Fokus masalah penelitian ini diuraikan menjadi beberapa pertanyaan penelitian yaitu bagaimanakah merancang pengembangan bahan ajar elektronik berbasis m-learning menggunakan smartphone pada matakuliah matematika dasar, bagaimanakah mengimplementasikan rancangan pengembangan bahan ajar elektronik berbasis m-learning menggunakan smartphone untuk meningkatkan kemampuan dan kemandirian mahasiswa dalam penguasaan teknologi, bagaimanakah mengevaluasi kemampuan mahasiswa pada matakuliah matematika dasar, dan bagaimanakah efektivitas pengembangan bahan ajar elektronik berbasis $m$ learning menggunakan smartphone.

\section{METODE PENELITIAN}

Metode penelitian ini yaitu research and development $(R \& D)$ dengan desain $4 \mathrm{D}$, yaitu tahap define, design, develop, dan disseminate yang dibatasi sampai tahap develop (Gambar 1). Tahapan define berisi analisis kebutuhan, kajian pustaka, tujuan penelitian, identifikasi serta analisis kebutuhan. Tahapan design dilakukan penyusunan bahan ajar dan tes, kemudian membuat desain bahan ajar pada smartphone dengan bantuan ahli media. Hal ini dimaksudkan, ahli media tersebut membuat aplikasi sesuai dengan bahan ajar yang sudah dirancang, sehingga sesuai dan dapat digunakan oleh peneliti. Tahap pengembangan dilakukan validasi bahan ajar kemudian uji terbatas dan uji luas. Sampel dalam uji terbatas dan uji luas adalah Mahasiswa Program Studi Bahasa Inggris di STKIP Muhammadiyah Manokwari. Uji terbatas dilakukan oleh 10 mahasiswa yang bertujuan untuk mengetahui penilaian produk dalam bentuk aplikasi mobile sebelum dilakukan tahap uji luas.

Penilaian tersebut untuk mengetahui kemampuan penggunaan mahasiswa terhadap penggunaan teknologi. Penilaian berdasarkan tingkat pemahaman dalam pengoperasian aplikasi. Setelah mendapatkan hasil dari uji terbatas, dilakukan revisi untuk melakukan evaluasi terhadap produk, dilanjutkan dengan uji luas yang berjumlah 30 mahasiswa. Semua hasil penilaian yang diperoleh dari mahasiswa dianalisis dengan skoring menggunakan angket. Angket respons terhadap penggunaan produk memiliki empat pilihan jawaban sesuai konten pertanyaan, misalnya "sangat menarik", "menarik", "kurang menarik", dan "tidak menarik". Masingmasing pilihan jawaban memiliki skor berbeda yang mengartikan tingkat kesesuaian produk bagi pengguna. Hasil dari skor penilaian tersebut kemudian dicari rata-ratanya dari sejumlah subyek sampel uji coba. Kemudian, pernyataan penilaian dikonversikan untuk menentukan tingkat kemenarikan, kemudahan dan kemanfaatan bahan ajar elektronik yang dihasilkan. Tahapan terakhir menghitung dan menganalisis hasil ratarata yang diperoleh.

Untuk mengetahui nilai rerata skor menggunakan persamaan dibawah

$$
\text { Rerata Skor }(\bar{X})=\frac{\text { Jumlah Total Skor }\left(\sum x\right)}{\text { Jumlah Penilai } \times \text { Jumlah Item }}
$$

Untuk memngetahui persentase keidealan produk aplikasi, digunakan persamaan dibawah

$$
\text { Keidealan }(\overline{\%})=\frac{\text { Jumlah Skor yang didapatkan }(\%)}{\text { Skor Maksimal }} \times 100 \%
$$


https://jurnal.unsulbar.ac.id/index.php/saintifik

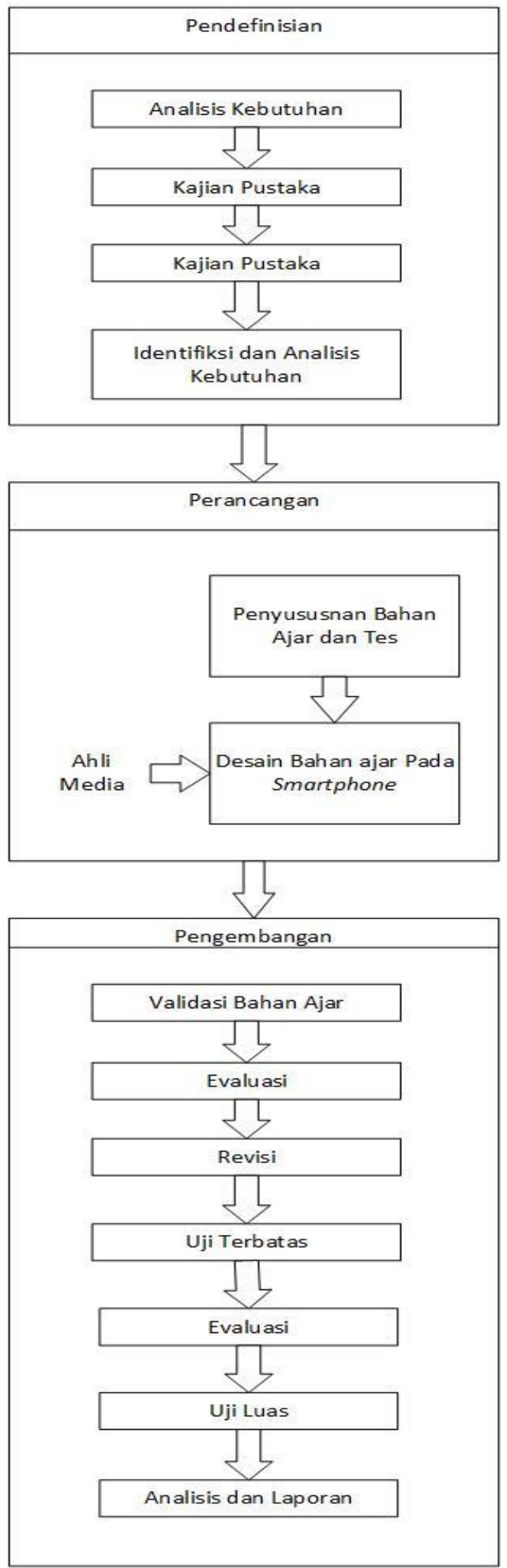

Gambar 1 Desain penelitian pengembangan tipe 4D 


\section{HASIL DAN PEMBAHASAN}

Hasil utama penelitian ini adalah pengembangan bahan ajar elektronik pada Mata Kuliah Matematika Dasar dengan menggunakan smartphone. Subyek penelitian, yaitu mahasiswa Prodi Bahasa Inggris STKIP Muhammadiyah manokwari. Pembuatan media m-learning menggunakan Android Studio, yang dibuat oleh ahli media. Peneliti memberikan komponen dari bahan ajar dan desain bahan ajar yang dinginkan. Bahan ajar elektronik berisi Mata Kuliah Matematika Dasar, yang terdiri dari silabus singkat, Materi 9 bab, Soal dan petunjuk pengerjaan, dan soal yang berisi tes dan jawaban serta skor stelah dijawab.

Analisis kebutuhan dilakukan dengan cara memberikan angket dan observasi kepada mahasiswa. Hasil yang diperoleh dari penyebaran angket dan observasi menunjukkan sebesar $57 \%$ mahasiswa memiliki nilai dengan rentang $\mathrm{E}-\mathrm{C}$. Hal tersebut membuktikan bahwa masih rendahnya kemampuan memahami matematika dasar, sehingga perlu bahan ajar untuk meningkatkan pemahaman mahasiswa tersebut. Adanya peningkatan pemahaman diharapkan adanya peningkatan nilai kuliah pada mahasiswa tersebut. Bahan ajar elektronik dengan menggunakan smartphone diterapkan agar mahasiswa dapat belajar kapanpun dan dimanapun.

Revisi media elektronik dilakukan oleh ahli media. Peneliti memberikan masukan, sehingga dilakukan beberapa revisi sebelum melakukan uji terbatas. Adanya revisi bertujuan untuk memeperoleh bahan ajar elektronik yang mendukung penelitian. Isi bahan ajar yang diterapkan di validasi oleh validator yang berkompeten dibidang Matematika dengan hasil pada Tabel 1

Tabel 1 Hasil validasi bahan ajar

\begin{tabular}{|l|c|l|}
\hline Aspek yang dinilai & Skor & \multicolumn{1}{|c|}{ Kriteria } \\
\hline Keterbacaan Modul & 4 & Sangat jelas dan dapat dipergunakan tanpa revisi \\
\hline Kejelasan tulisan & 4 & Sangat jelas dan dapat dipergunakan tanpa revisi \\
\hline Kedalaman materi & 2 & Cukup, sehingga perlu ditingkatkan \\
\hline Bentuk Penyajian & 3 & Bagus \\
\hline Kelengkapan Bahan Ajar & 3 & Baik dan sesuai sehingga dapat dipergunakan \\
\hline
\end{tabular}

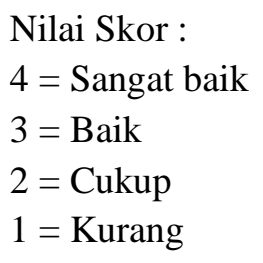

Berdasarkan hasil dari validasi ahli disimpulkan bahwa bahan ajar matematika dapat dipergunakan tanpa revisi. Kemudian tahapan awal, bahan ajar elektronik disebarkan pada 10 mahasiswa sebagai uji terbatas. Hasil uji terbatas diperoleh pada Tabel 2.

Tabel 2. Uji Terbatas Bahan Ajar Elektronik

\begin{tabular}{|l|l|c|c|c|c|}
\hline \multirow{2}{*}{ No } & Item Penilaian pada Angket & \multicolumn{4}{|c|}{ Skor (\%) } \\
\cline { 3 - 6 } & & $\begin{array}{c}4 \\
\text { (Sangat } \\
\text { Tinggi) }\end{array}$ & $\begin{array}{c}3 \\
\text { (Tinggi) }\end{array}$ & $\begin{array}{c}2 \\
\text { (Sedang) }\end{array}$ & $\begin{array}{c}1 \\
\text { (Rendah) }\end{array}$ \\
\hline 1 & Kejelasan Materi & 85,1 & 13,4 & 1,5 & 0 \\
\hline
\end{tabular}


https://jurnal.unsulbar.ac.id/index.php/saintifik

\begin{tabular}{|l|l|c|c|c|c|}
\hline 2 & $\begin{array}{l}\text { Membantu mahasiswa } \\
\text { dalam belajar }\end{array}$ & 52,33 & 39 & 3 & 5,67 \\
\hline 3 & $\begin{array}{l}\text { Keterbacaan tulisan dalam } \\
\text { bahan ajar elektronik }\end{array}$ & 78,5 & 18,4 & 3,1 & 0 \\
\hline 4 & $\begin{array}{l}\text { Kebermanfaatan bahan ajar } \\
\text { elektronik }\end{array}$ & 65,71 & 27,19 & 1,55 & 5,55 \\
\hline 5 & $\begin{array}{l}\text { Bahan ajar elektronik perlu } \\
\text { pengembangan }\end{array}$ & 88 & 10,8 & 1,2 & 0 \\
\hline 6 & $\begin{array}{l}\text { Tampilan materi dalam } \\
\text { aplikasi }\end{array}$ & 78,1 & 20 & 1,9 & 0 \\
\hline
\end{tabular}

Berdasarkan hasil uji coba terbatas dihasilkan produk akhir yang siap untuk digunakan pada uji luas dengan jumlah 30 siswa yang hasilnya terlihat pada Tabel 3. Bahan ajar ini hanya dapat dijalankan di perangkat yang berbasis android. Pengembangan bahan ajar elektronik ini memiliki beberapa kelebihan, yaitu produk dapat menyesuaikan dengan layar android yang dimiliki dan dapat digunakan sebagai alternatif pemecahan masalah dalam keterbatasan bahan ajar yang ada serta menyediakan sumber belajar yang bervariasi dan menarik bagi mahasiswa yang berupa media $m$-Learning berbasis android.

Tabel 3 Uji luas bahan ajar elektronik

\begin{tabular}{|c|c|c|c|c|c|}
\hline \multirow[t]{2}{*}{ No } & \multirow{2}{*}{$\begin{array}{c}\text { Item Penilaian pada } \\
\text { Angket }\end{array}$} & \multicolumn{4}{|c|}{ Skor (\%) } \\
\hline & & $\begin{array}{c}4 \\
\text { (Sangat Tinggi) }\end{array}$ & $\begin{array}{c}3 \\
\text { (Tinggi) }\end{array}$ & $\begin{array}{c}2 \\
\text { (Sedang) }\end{array}$ & $\begin{array}{c}1 \\
\text { (Rendah) }\end{array}$ \\
\hline 1 & Kejelasan Materi & 80 & 15,5 & 3,5 & 0 \\
\hline 2 & $\begin{array}{l}\text { Membantu mahasiswa } \\
\text { dalam belajar }\end{array}$ & 62,33 & 29 & 4,6 & 4,07 \\
\hline 3 & $\begin{array}{lr}\text { Keterbacaan tulisan } \\
\text { dalam bahan ajar } \\
\text { elektronik }\end{array}$ & 75,5 & 21,1 & 3,4 & 0 \\
\hline 4 & $\begin{array}{l}\text { Kebermanfaatan bahan } \\
\text { ajar elektronik }\end{array}$ & 69,71 & 23,19 & 5,55 & 1,55 \\
\hline 5 & $\begin{array}{l}\text { Bahan ajar elektronik } \\
\text { perlu pengembangan }\end{array}$ & 86,1 & 6,8 & 7,1 & 0 \\
\hline 6 & $\begin{array}{l}\text { Tampilan materi dalam } \\
\text { aplikasi }\end{array}$ & 80,5 & 17,9 & 1,6 & 0 \\
\hline
\end{tabular}

Adanya bahan ajar elektronik yang diuji secara luas terlihat bahwa ada beberapa mahasiswa yang kurang kemampuan dalam menggunakan bahan ajar ini. Tabel 3 terlihat pada item penilaian membantu mahasiswa dalam belajar dan kebermaanfaatan modul skornya paling rendah. Pembelajaran merupakan suatu tindakan sadar dari seorang pendidik untuk membelajarkan para peserta didiknya dalam rangka mencapai suatu tujuan yang dikehendaki (Sugiyono, 2005). Salah satu faktor yang berpengaruh pada sistem pembelajaran adalah adanya sarana pembelajaran seperti media, alat- alat pembelajaran, perlengkapan, yang mendukung kelancaran proses pembelajaran itu sendiri (Sanjaya dan Wina, 2013). Adanya bahan ajar elektronik sebagai media dalam membantu mahasiswa dalam pembelajaran diperlukan, tetapi adanya evaluasi dalam penggunaan diperlukan. 
Evaluasi terhadap peningkatan nilai dilaksanakan tidak secara menyeluruh. Kemampuan mahasiswa terlihat dari menjawab soal yang dikerjakan dan tes dengan skor langsung yang bisa dilihat. Hanya saja tes langsung mempunyai soal dengan pilihan ganda dan terbatas serta tidak ada pembaharuan. Hal tersebut sesuai dengan pendapat Polonia (2014) yang menyatakan bahwa kekurangan produk media pembelajaran $m$-Learning memiliki ruang lingkup materi yang terbatas dan harus dilakukan pembaruan.

Soal yang dibuat terdiri dari 10 soal pilihan ganda. Ada beberapa soal yang dikerjakan dikertas untuk dikumpulkan dan diperiksa. Dari hasil yang diperoleh dari 30 mahasiswa hanya 10 orang yang mempunyai nilai dibwah 50, sedangkan 20 orang, rata-rata rentang 51-100. Hasil ini memperlihatkan adanya keefektifan bahan ajar elektronik sebesar $67 \%$. Hal ini menunjukkan bahan ajar elektronik masuk kategori cukup baik dan efektif digunakan sebagai bahan ajar. Bahan ajar elektronik dapat menambah pemahaman mahasiswa mengenai materi yang dijelaskan dosen didalam kelas.

\section{KESIMPULAN}

Penelitian ini menghasilkan bahan ajar elektronik yang dikembangkan pada mata kuliah matematika dasar. Pengembahan bahan ajar elektronik ini berbasis android dibuat oleh ahli media dan telah tervalidasi kesesuaiannya. Setelah itu dilakukan uji terbatas pada 10 mahasiswa dan uji luas pada 30 mahasiswa. Bahan ajar elektronik ini hanya dapat dijalankan diperangkat yang berbasis mobile.

Pengembangan bahan ajar elektronik ini memiliki beberapa kelebihan sebagai alternatif pemecahan masalah dalam keterbatasan bahan ajar yang ada Bahan ajar elektronik masuk kategori cukup baik dan efektif digunakan sebagai bahan ajar. Bahan ajar elektronik dapat menambah pemahaman mahasiswa mengenai materi yang dijelaskan dosen didalam kelas.

Pengembangan bahan ajar elektronik belum berisi soal ataupun test dalam bentuk uraian. Selain itu, bahan ajar elektronik belum dikembangkan agar dapat diakses secara daring agar mendapat pembaruan materi secara berkala. Oleh karena itu, perlunya penelitian lanjut untuk memperbaiki kekurangan pengembangan bahan ajar elektronik yang akan datang.

\section{DAFTAR PUSTAKA}

Arsyad, Azhar. 2013. Media Pembelajaran. Jakarta: Rajawali Pers.

Dwiyogo, Wasis D. 2013. Media Pembelajaran. Malang: Wineka Media.

Jazulil, M., Azizah, F. L., dan Meita, M. N., 2017. Pengembangan Bahan Ajar Elektronik Berbasis Android Sebagai Media Interaktif. Jurnal Lensa (Lentera Sains): Jurnal Pendidikan IPA (online), volume 7 , No.47, diakses 20 Agustus 2018

Munadi, Yudhi. 2013. Media Pembelajaran. Jakarta: GP Press Group.

Prastowo, Andi. 2011. Panduan Kreatif Membuat Bahan Ajar Inovatif, Menciptakan Metode Pembelajaran yang Menarik dan Menyenangkan. Jogjakarta: DIVA Press.

Sanjaya, Wina. 2013. Kurikulum dan Pembelajaran: Toeori dan Praktik Pengembangan Kurikulum Tingkat Satuan Pendidikan (KTSP). Jakarta: Kencana Prenada Media Group. 
https://jurnal.unsulbar.ac.id/index.php/saintifik

Sugiyono. 2015. Metode Penelitian Pendidikan. Bandung: Alfabeta.

Sungkono. 2003. Pengembangan Dan Pemanfaatan Bahan Ajar Modul Dalam Proses Pembelajaran. Makalah Yogyakarta: FIP UNY 